Article - Human and Animal Health

\title{
Investigation of New Benzimidazole Derivative Compounds' Effects on A549 Cell Line
}

\section{Gülay Gülbol Duran ${ }^{1}$}

https://orcid.org/0000-0002-4672-2960

Meral Urhan Küçük ${ }^{1}$

https://orcid.org/0000-0003-1704-1370

\section{Öztekin Algül ${ }^{2}$}

https://orcid.org/0000-0001-5685-7511

\section{Menderes Yusuf Terzi ${ }^{1 *}$}

https://orcid.org/0000-0001-8478-0451

${ }^{1}$ Hatay Mustafa Kemal University, Faculty of Medicine, Department of Medical Biology, Hatay, Turkey; ${ }^{2}$ Mersin University, Faculty of Pharmacy. Department of Pharmaceutical Chemistry, Mersin, Turkey.

Received: 2019.06.14; Accepted: 2020.03.17.

*Correspondence: menderesyusufterzi@gmail.com, myterzi@mku.edu.tr; Tel.: +90-32-62455114 extension: 17079, Tel (GSM): +90-53-072256 32

\section{HIGHLIGHTS}

- ORT-83 exerted its anti-inflammatory effects on A549 cells.

- ORT-83 reduced NFkB, IL-6, TNF- $\alpha$, iNOS levels after IL-1 $\beta$-induced inflammation.

- ORT-83 caused a milder suppression on COX-2 than Dexamethasone.

- ORT-83 did not affect IL-10 expression like Dexamethasone.

Abstract: Chronic inflammation is a common indication of several diseases, e.g. asthma, chronic obstructive pulmonary disease (COPD), atherosclerosis, etc. Benzimidazole derivatives are preferable compounds to design new analgesic and anti-inflammatory substances due to their unique biological features. We aimed to investigate the effect of a newly synthesized benzimidazole derivative, ORT-83, on A549 human lung adenocarcinoma cell line. ORT-83 was synthesized, and a non-cytotoxic concentration of ORT-83 on A549 cells was detected with MTT assay. To analyze the anti-inflammatory effect of ORT-83, an inflammatory cell culture model was established by stimulating A549 cell line with IL1- $\beta(10 \mathrm{ng} / \mathrm{ml})$. After 2 hours of treatment with IL1- $\beta$ to induce inflammation, A549 cells were exposed to ORT-83 $(0.78 \mu \mathrm{g} / \mathrm{ml})$ for 24 hours. Thereafter gene expression analyses were performed with qRT-PCR. We found that ORT-83 significantly suppressed the gene expression levels of the proinflammatory cytokines; IL-6, NFkB, and TNF- $\alpha$. However, the increased levels of IL-10 (2.8 folds) by IL-1 $\beta$ induction did not change after ORT-83 and/or dexamethasone (Dex: positive control) treatments. While Dex; a COX-2 inhibitor, reduced the COX-2 expression level in inflammatory cells from 10.03 folds to 0.71 folds, ORT-83 reduced its level to 4.37 folds. iNOS expression levels did not change in any experimental groups. In conclusion, we showed that ORT-83 exerted its antiinflammatory effects by repressing the gene expression of proinflammatory cytokines in the inflammation- 
induced A549 cell line. Although ORT-83 had a weaker COX-2 inhibitory effect compared to Dex, it was shown to be still a strong anti-inflammatory compound.

Keywords: A549; benzimidazole; inflammation; anti-inflammatory.

\section{INTRODUCTION}

Inflammation is a biological response by immune cells against infectious agents and injuries [1-4]. Inflammation, which is a multiple process, comprises many inflammatory mediators. These mediators are modulated by both innate and acquired immune cells [1,5]. The macrophages that are immune cells taking part in inflammation are involved in the onset of several immunopathological events like the excessive production of inflammatory mediators [reactive oxygen species (ROS), nitric oxide (NO) and prostaglandin E2 (PGE2)] induced by proinflammatory cytokines iNOS and COX-2 [6-9]. NFKB is an inducible transcription factor which targets the genes playing a role in the progression of the inflammation. Post-activation, NFKB regulates inflammation by activating the transcription of several genes that function in inflammatory processes [3].

There should be always a balance between the beneficial effects of inflammation on the defense mechanism and the long term cell-destruction potential of inflammatory reactions. If this balance is disturbed or not properly regulated, the emerged chronic inflammation can cause many diseases $[1,5]$. The first choice in the treatment of inflammation-related diseases is non-steroidal anti-inflammatory drugs (NSAID) $[4,10]$. NSAID has been used from the past to the present by millions of patients worldwide with a success in the removal of inflammation and pain [11]. But the long-term utilization of this type of drugs is limited due to their adverse effects. In this manner, some selective COX-2 inhibitors with anti-inflammatory effects were developed to reduce the side effects of NSAID arising from their acute and chronic use. However, the selective COX-2 inhibitors are also not recommended clinically due to their adverse effects on the cardiovascular system [9].

Benzimidazoles and their derivatives, as members of heterocyclics, are popular compounds used for the discovery of novel drugs in pharmaceutics and medical chemistry [12-15]. The recent fact that benzimidazole derivatives have unique structural and biological activities makes them prominent compounds in the design of new drugs. Some of these activities are primarily analgesic and anti-inflammatory $[11,13]$ as well as antihypertensive, antibacterial, antifungal, anthelmintic, antiviral, antioxidant, antiulcer, antitumor, and psychoactivity features [11-17].

The discovery of novel compounds is crucial to minimize side effects in the treatment of the diseases coursing with chronic inflammation. Thus in the present study, we investigated the effect of a newly synthesized benzimidazole derivative coded as ORT-83 on A549 human lung adenocarcinoma cell line.

\section{MATERIALS AND METHODS}

\section{Synthesis of benzimidazole derivative}

Philips procedure was used in the synthesis of the benzimidazole derivative ORT-83. The molecular structure of the synthesized compound was verified with IR (infrared spectroscopy), 1H-NMR (1H Nuclear Magnetic Resonance Spectroscopy), and MS (mass spectroscopy) methods.

\section{Cell culture}

Adenocarcinoma of the alveolar type II pneumocytes cell line A549 (ATCC, LGC Promochem, Teddington, UK) was cultured as $1 \times 105 \mathrm{cell} / \mathrm{mL}$ by using DMEM culture medium (Dulbecco's Modified Eagle Medium, Gibco, İnvitrogen) including 10\% FCS, $2 \mathrm{mM} \mathrm{L-glutamine,} \mathrm{and} \mathrm{1 \%} \mathrm{penicillin/streptomycin} \mathrm{in} 37{ }^{\circ} \mathrm{C}$ incubator with $95 \%$ humidity and $5 \% \mathrm{CO}$. The cells were passaged ( 1:8 ratio) after trypsinization when 70 $80 \%$ confluency was reached.

For further experiments, the cells were harvested and sub-cultured into cell plates. After confluency was reached, the complete medium was exchanged with serum free DMEM medium and incubated for 24 hours (h). In order to induce inflammation, the cells were treated with IL-1 $\beta$ for $2 \mathrm{~h}$. After incubation, the cells were treated with various concentrations of ORT-83 to analyze cell viability with MTT assay. Thereafter, the cells were seeded into 6-well plates and treated with the non-cytotoxic dosage of ORT-83 for $24 \mathrm{~h}$ to analyze gene expressions. 


\section{Cell viability assay}

The effect of benzimidazole derivative ORT-83 on cell viability was assessed with MTT assay. For this purpose, serial dilutions of ORT-83 were prepared with SF DMEM medium as the following: 100, 50, 25, $12.5,6.25,3.125,0.78$, and $0 \mu \mathrm{g} / \mathrm{mL}$. A549 cells were seeded into 24-well plates as $0.5 \mathrm{ml}$ per well with the cell density of 5000 cells $/ \mathrm{ml}$. After plates reached $70-80 \%$ cell density, the complete medium was exchanged with SF medium for further 24h incubation. Then the cells were treated with various concentrations of OTR83 for another $24 \mathrm{~h}$. Thereafter the cell media were aspirated and $1 \mathrm{mg} / \mathrm{ml} \mathrm{MTT} \mathrm{(3-(4,5-dimethylthiazol-2-yl)-}$ 2,5-diphenyltetrazolium bromide, Sigma) was added into each well and incubated for $4 \mathrm{~h}$. Finall MTT solution was removed and $0.5 \mathrm{ml}$ DMSO solution was added into each well to solve purple formazan crystals. After 5 minutes incubation at room temperature, the color change was measured with a spectrophotometer (MultiScan Go, ThermoFisher, Finland) at $590 \mathrm{~nm}$ and $670 \mathrm{~nm}$ (reference) wavelengths.

\section{Quantitative reverse transcription-polymerase chain reaction (qRT-PCR)}

A549 cells were seeded into 6 -well plates at a cell density of 5000 cells $/ \mathrm{ml}$ and incubated until $70-80 \%$ confluency. The cells were treated with $10 \mathrm{ng} / \mathrm{ml} \mathrm{IL-1 \beta}$ to induce inflammation for $4 \mathrm{~h}$ and then exposed to ORT-83 $(0.78 \mu \mathrm{g} / \mathrm{ml})$ for $24 \mathrm{~h}$. After the incubation, the treatment and control plates were harvested for RNA isolation by using a total RNA isolation kit (Thermo Scientific GeneJET). Dexamethasone (Dex, $1 \mu \mathrm{M})$, an anti-inflammatory agent, was used as positive control [18-20]. Total RNA samples were used to obtain cDNA via reverse transcription with cDNA synthesis Kit (Applied Biosystems). Finally, gene expression levels of IL6 , TNF- $\alpha$, IL-10, COX-2, iNOS, and NFKB were measured with qRT-PCR method by using specific primers and melting temperatures as summarized in Table 1. The cycling conditions are as follows: Initial denaturation at $95^{\circ} \mathrm{C}$ for 10 minutes, 40 cycles of $95^{\circ} \mathrm{C}$ for 15 seconds, $60^{\circ} \mathrm{C}$ for 60 seconds. The expression levels were calculated with $2-\Delta \Delta \mathrm{Ct}$ method and expressed as folds changes compared to the untreated control group.

\section{Statistical analysis}

GraphPad Prism Version 5.01 software was used to analyze cell viability assay. Kolmogorov-Smirnov test was used to analyze whether there is any normal distribution within groups. Kruskal-Wallis test was performed to compare the differences among groups. Dunn's Multiple Comparison Test was used to find out significant differences between individual groups. Each treatment group was compared to the control group.

Gene expression analyses were performed by utilizing an online data analysis center (Qiagen, RT2 profiler PCR Array Data Analysis version 3.5). $\beta$-actin house-keeping gene was used for the normalization of the data. All graphics were plotted with GraphPad Prism 5.01.

Table 1. The primers and cycling conditions used for gene expression analyses (qRT-PCR)

\begin{tabular}{cccccc}
\hline $\begin{array}{c}\text { Gene } \\
\text { Symbols }\end{array}$ & $\begin{array}{c}\text { Primer } \\
\text { Codes }\end{array}$ & $\begin{array}{c}\text { Product } \\
\text { Size (bp) }\end{array}$ & $\begin{array}{c}\text { Annealin } \\
\mathbf{g ~}\left({ }^{\circ} \mathbf{C}\right)\end{array}$ & Cycle & $\begin{array}{c}\text { Reference } \\
\text { Sequences }\end{array}$ \\
\hline IL-6 & PPH00560C & $98 \mathrm{bp}$ & 60 & $40 \mathrm{x}$ & NM_000600 \\
TNF-a & PPH00341F & $110 \mathrm{bp}$ & 60 & $40 \mathrm{x}$ & NM_000594 \\
IL-10 & PPH00572C & $63 \mathrm{bp}$ & 60 & $40 \mathrm{x}$ & NM_000572 \\
COX-2 & PPH01136F & $63 \mathrm{bp}$ & 60 & $40 \mathrm{x}$ & NM_000963 \\
iNOS & PPH00173F & $71 \mathrm{bp}$ & 60 & $40 \mathrm{x}$ & NM_000625 \\
NFKB & PPH00204F & $81 \mathrm{bp}$ & 60 & $40 \mathrm{x}$ & NM_001165412 \\
$\beta-A c t i n$ & PPH00073G & $174 \mathrm{bp}$ & 60 & $40 \mathrm{x}$ & NM_001101 \\
\hline
\end{tabular}

IL-6: Interleukin-6, TNF- $\alpha$ : Tumor necrosis factor alpha, IL-10: Interleukin-10, COX-2: Cyclooxygenase-2, iNOS: Inducible nitric oxide synthase, NFkB: Nuclear factor kappa B, $\beta$-Actin: Beta actin.

\section{RESULTS}

\section{Synthesis of benzimidazole derivative}

$3 \mathrm{mmol} 0.427 \mathrm{~g}$ 4-chloro-1,2-phenilendiamin, $3.3 \mathrm{mmol} 0.562 \mathrm{~g}$ 4-chloropheil acetic acid were taken into a test tube and $20 \mathrm{ml} 5 \mathrm{~N} \mathrm{HCl}$ was added. The solution was heated. Then the solution was analyzed with thin layer chromatography and the reaction was terminated accordingly. The solution was crystalized with water/ethanol for about 161 hours. The efficiency of the reaction was $60 \%$ and the melting point was 155 $158{ }^{\circ} \mathrm{C}$. The chemical structure of newly synthesized benzimidazole derivative ORT-83 was depicted in Figure 1 [21]. 


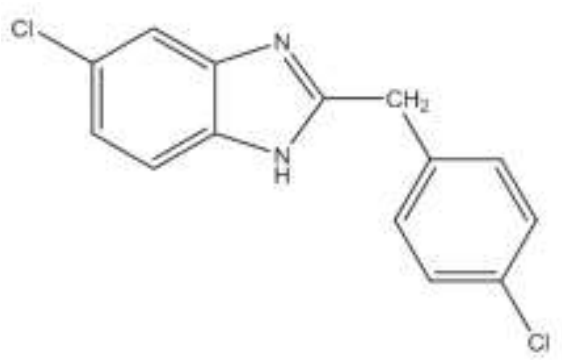

Figure 1. The chemical structure of newly synthesized benzimidazole derivative ORT-83.

\section{The evaluation of cell viability}

The effect of ORT-83 on A549 cell viability was analyzed with MTT assay. Based on the results, the noncytotoxic concentration of the compound was determined.

The cell viability ratio at $0.78 \mu \mathrm{g} / \mathrm{ml}$ concentration of ORT-83, which showed the least cytotoxicity on the cells, was assessed as $89.37 \%$. This concentration was preferred for the further gene expression analyses since it exhibited the highest cell viability ratio and had no significant difference compared to the control (Figure 2).

\section{ORT83-MTT}

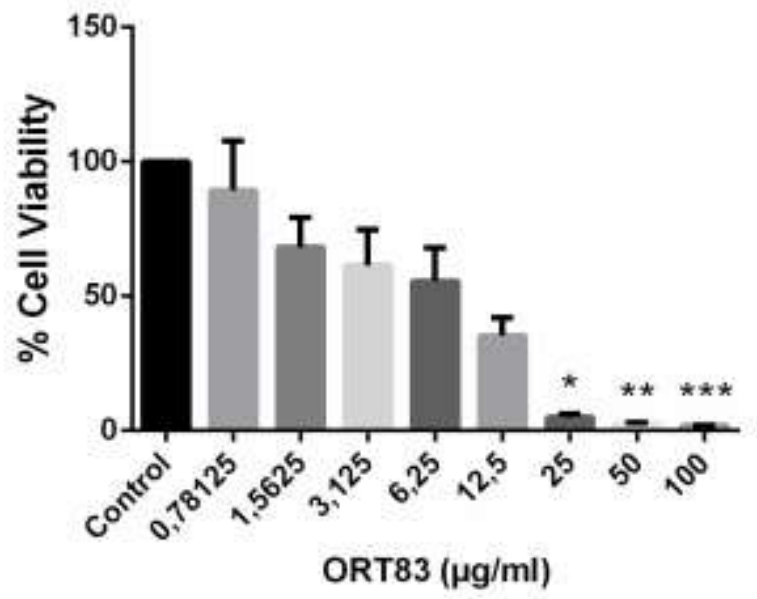

Figure 2. Cell viability levels after $24-\mathrm{h}$ treatment of different ORT-83 doses $(100-0 \mu \mathrm{g} / \mathrm{ml})$ in A549 cells. The data were presented as percentage (\%) of untreated control and mean \pm SEM. $(n=6),{ }^{*} p<0.05,{ }^{* *} p$ $<0.01,{ }^{* \star} \mathrm{p}<0.001$.

\section{Gene expression levels of inflammation-related markers}

The alterations in the gene expression levels of NFkB, IL-6, and TNF- $\alpha$ after treatment of IL-1 $\beta$-induced $(10 \mathrm{ng} / \mathrm{ml}$ for $2 \mathrm{~h}$ ) inflammatory A549 cells with ORT-83 for $24 \mathrm{~h}$ in were depicted in Figure 3 . The fold changes in gene expression levels in all groups were calculated based on untreated non-inflammatory A549 cells.

NFkB gene expression level was upregulated by 7.58 folds in $2 \mathrm{~h}$-long inflammation-induced cells (IL-1 $\beta$ group) compared to the control. Dex, as the positive control, decreased NFkB level down to 1.86 folds whereas ORT-83 down to 2.64 folds significantly compared to the IL-1 $1 \beta$ group. Similarly, the combination of ORT-83 and Dex significantly decreased NFkB level to 1.95 folds (Figure $3 A, p<0.05$ ).

With a similar effect, IL-6 level increased by 199 folds in IL-1 $\beta$-induced cells compared to the control group and Dex treatment decreased this level down to 31 folds and ORT-83 down to 66.01 folds significantly compared to the IL-1 $\beta$ group. ORT-83 and Dex combination caused even further downregulation in IL- 6 level until 19.36 folds (Figure $3 \mathrm{~B}, \mathrm{p}<0.05$ ).

TNF- $\alpha$ level was also significantly upregulated by 3650 folds in IL-1 $\beta$ group compared to the control. Dex decreased TNF- $\alpha$ level down to 19.73 folds and ORT-83 down to 46.67 folds significantly compared to the IL-1 $\beta$ group. The combination of Dex and ORT-83 also led to a significant decrease in TNF- $\alpha$ level down to 21.85 folds (Figure $3 \mathrm{C}, \mathrm{p}<0.05$ ). 
A

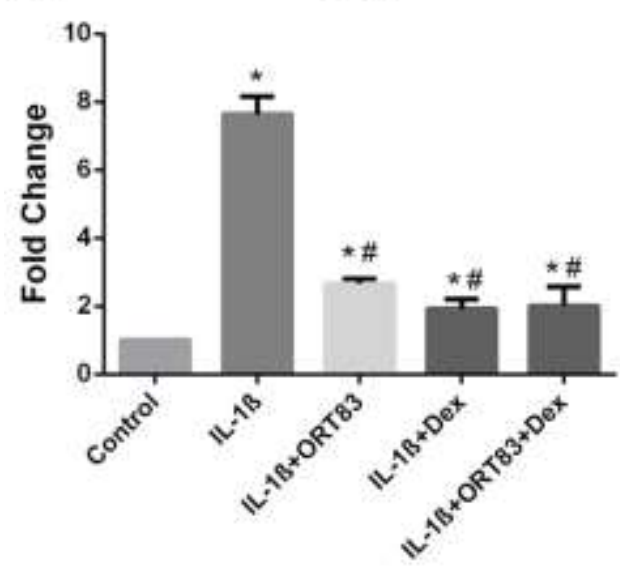

B

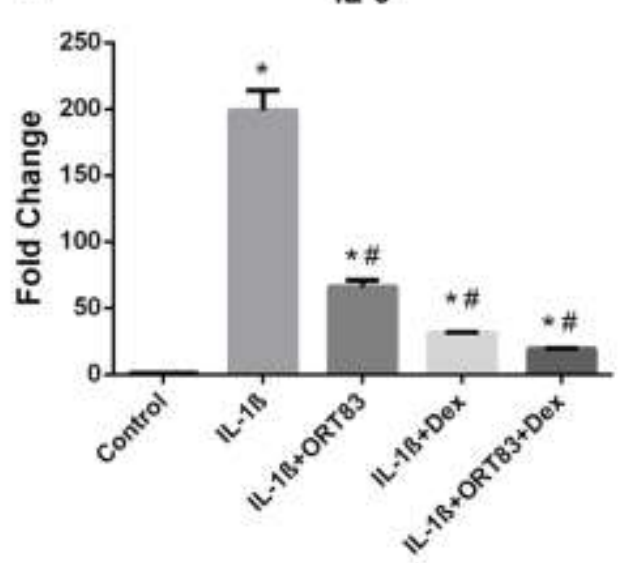

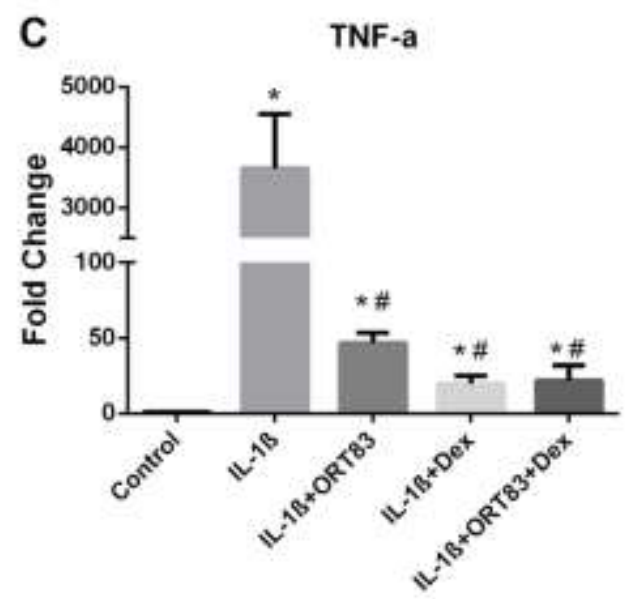

Figure 3. Gene expression changes of (A) NFkB, (B) IL-6, and (C) TNF- $\alpha$ after 24-h ORT-83 $(0.78 \mu \mathrm{g} / \mathrm{ml})$ and/or dexamethasone (Dex, $1 \mu \mathrm{M})$ treatments in IL-1 $\beta(10 \mathrm{ng} / \mathrm{ml}$ for $2 \mathrm{~h}$ )-induced inflammatory A549 cell line. The data were presented as folds change compared to the untreated "Control" cells and mean \pm SEM. $n=6,{ }^{*} p<0.05$ compared to the "Control" group, $\# p<0.05$ compared to the IL-1 $\beta$ group.

The gene expression levels of IL-10, as an anti-inflammatory cytokine, were shown in Figure 4 A. While IL-10 level significantly increased by 2.8 folds in IL-1 $\beta$ group compared to the control $(p<0.05)$, Dex and/or ORT-83 treatments did not cause any significant change in IL-10 levels compared to the IL-1 $\beta$ group ( $p>0.05)$.

As shown in Figure 4 B, iNOS levels were significantly upregulated by 2.88 folds in IL- $\beta$ induced A549 cells compared to the control. Dex and ORT-83 treatments significantly decreased iNOS levels down to 1.4 and 1.8 folds respectively compared to IL-1 $\beta$ group $(p<0.05)$ while the combination of Dex and ORT-83 did not lead to any significant change $(p>0.05)$.

COX-2 gene expression level significantly increased by 10.03 folds in IL-1 $\beta$ induced inflammatory cells compared to the control. ORT-83 treatment reduced this level down to 4.37 folds while Dex caused a more drastic reduction untill 0.71 fold. The combined treatment of Dex and ORT-83 also downregulated COX-2 level to 0.76 fold compared to the IL-1 $\beta$ group (Figure $4 \mathrm{C}, \mathrm{p}<0.05$ ). 
A

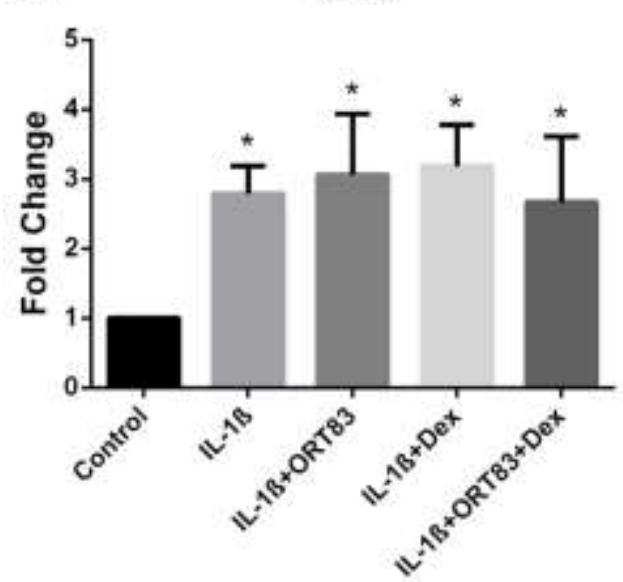

B

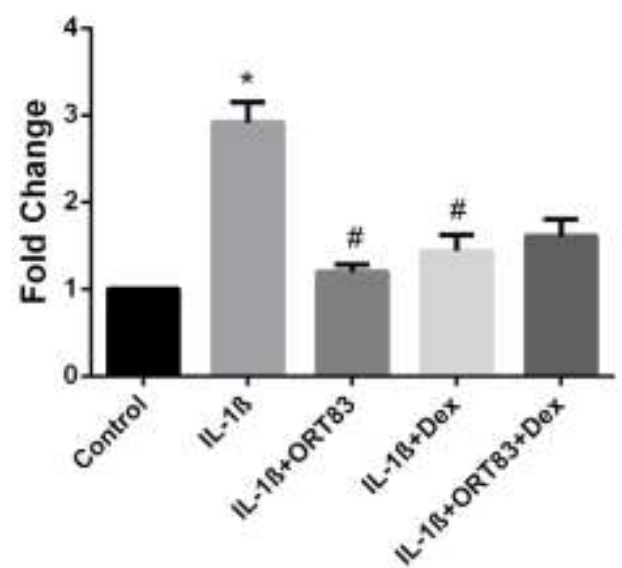

coX-2

C

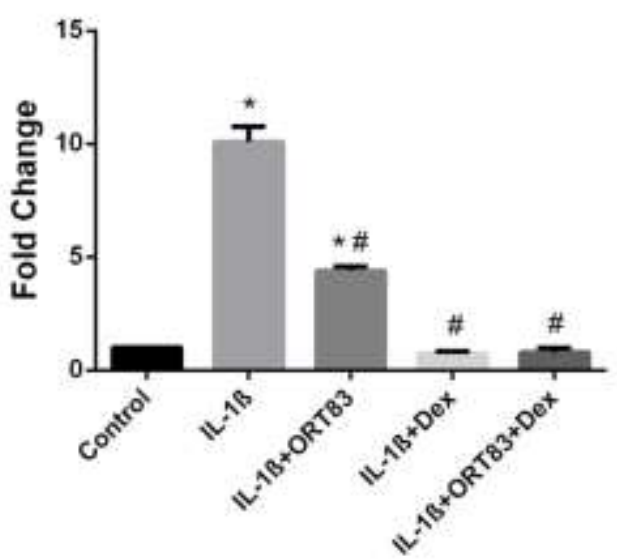

Figure 4. Gene expression changes of (A) IL-10, (B) iNOS, and (C) COX-2 after 24-h ORT-83 $(0.78 \mu \mathrm{g} / \mathrm{ml})$ and/or dexamethasone (Dex, $1 \mu \mathrm{M})$ treatments in IL-1 $\beta(10 \mathrm{ng} / \mathrm{ml}$ for $2 \mathrm{~h}$ )-induced inflammatory A549 cell line. The data were presented as folds change compared to the untreated "Control" cells and mean $\pm S E M$. $n=6,{ }^{*} p<0.05$ compared to the "Control" group, \#p $<0.05$ compared to the IL-1 $\beta$ group.

\section{DISCUSSION}

Inflammation is a crucial mechanism in host defense against infectious agents and injuries as well as its role in the pathophysiology of many chronic diseases [1,2]. NSAID is the first preference for the treatment of inflammation-related diseases. But these drugs have restricted long-term usage due to their side effects $[9,10]$. For this reason, the investigation and discovery of anti-inflammatory drugs with no or minimal side effects are highly important. Recently, benzimidazole compounds have emerged as a pharmacophore that is preferred for the design of anti-inflammatory analgesics. There are studies in the literature reporting that benzimidazole derivatives exhibit strong anti-oxidant activity at the $1 \mathrm{st}$ and 2 nd positions of their chemical structures $[12,14,15]$. With this respect, we evaluated the anti-inflammatory effects of a newly synthesized benzimidazole derivative called ORT-83 on A549 human lung adenocarcinoma cell line.

During the response to inflammatory reactions, several cytokines play role as the main mediators/promoters of the inflammatory processes. Two major subgroups of these proteins are pro- and anti-inflammatory cytokines. Pro-inflammatory cytokines, such as IL- 6 and TNF- $\alpha$, are involved at the beginning of the inflammatory process and lead to inflammatory response eventually [6,7]. As for antiinflammatory cytokines (IL-4, IL-10, IL-13, etc.), they suppress the inflammatory response by inhibiting the synthesis of other inflammatory cytokines $[6,22]$. IL-10 is originally known as "inhibitor of cytokine synthesis" since its basic function is suppressing the production/secretion of cytokines by T lymphocytes [22]. NF-kB mediates the expression of pro-inflammatory genes upon activation by TNF- $\alpha$ and triggers a series of inflammatory cascades [23].

In a study conducted by Liou and Huang, it was shown that IL-6, TNF- $\alpha$ and COX-2 expression levels decreased after casticin treatment in IL-1 $\beta$-induced inflammatory A549 cell line. In the same study, the suppression of NF-KB signaling cascade, which is the transcription factor of pro-inflammatory cytokines, was reported [24]. In line with this study, we also showed a significant reduction in the gene expression levels of 
NFKB, IL-6, TNF- $\alpha$ and COX-2 after ORT-83 treatment in IL-1 $\beta$-induced inflammatory A549 cell line. This reduction by ORT-83 exhibited a similar pattern of Dex as positive control which however had a stronger suppression on the aforementioned gene expression levels.

We also found that 7.58 folds increased NFkB expression levels in our inflammatory cell model reduced to 2.64 folds significantly after ORT-83 treatment. Similarly, IL-6 gene expression level increased by 199 folds after the induction of inflammation in A549. ORT-83 treatment suppressed IL-6 mRNA level down to 66.01 folds while Dex decreased these levels till 31 folds. The combined treatment of both Dex and ORT-83 suppressed IL-6 mRNA expression down to 19.36 folds which is a stronger reduction than the individual treatments of Dex and ORT-83. TNF- $\alpha$ levels showed a 3650-fold increase after induction of inflammation. ORT-83 reduced these levels down to 46.67 folds whereas Dex down to 19.73 folds. Similarly, the combination of Dex and ORT-83 decreased TNF- $\alpha$ mRNA levels to 21.85 folds.

Since NFkB is a transcription factor of pro-inflammatory cytokines, such downregulations in both IL-6 and TNF- $\alpha$, are expected $[2,7,25]$. In our study, the fact that ORT-83 suppressed the gene expression levels of IL- 6 and TNF- $\alpha$ together with NFkB suggested that ORT-83 has an anti-inflammatory effect on IL-1 $\beta$ induced A549 cells.

One of the primarily preferred drug groups in the treatment of inflammatory diseases is COX-2 inhibitors. However COX-2 inhibitors have side effects on the cardiovascular system and inhibit the protective and suppressive impacts of COX-2 in several cancer types. Therefore, the long-term utilization of such drugs is risky. Huang and coauthors reported in a study conducted with inflammatory cell model induced by IL-1 $\beta$ that the treatment with a flavonoid called phloretin decreased the COX-2 expression in A549 cells [26]. Similar to this study, we also observed a significant decrease in COX-2 expression after ORT-83 treatment untill 4.37 folds compared to the 10.03-fold increase in untreated inflammatory cells. Dex treatment showed more reduction down to 0.71 fold compared to ORT-83 which shows that ORT-83 is not a strong COX-2 suppressor, unlike Dex. On the other hand, the adverse effects of COX-2 inhibitors, like Dex, are clinically unfavorable. Thus, we consider that ORT-83 is a compound that has a promising drug potential with no side effects together with its anti-inflammatory effects, despite milder COX-2 inhibition than Dex.

Cytokines-induced NOS (iNOS) is secreted as a result of induction by macrophages or other stimulants [27]. Ravichandran and coauthors demonstrated a strong induction of iNOS expression after IL-1 $\beta$ treatment of A549 cells [28]. Similar to this study, we also observed that iNOS gene expression showed a 2.88-fold increase after IL-1 $\beta$ induction but this increase was not significant since $p$-value was at the borderline $(p=0.059)$. We also found no significant changes in iNOS mRNA levels after either ORT-83 (1.18 folds) or Dex (1.4 folds) treatment.

At last but not least, these results are just representing the effect of a newly synthesized chemical synthetic compound on gene expression level in the scale of an inflammatory cell line model. In this regard, the major limitations of the present study are lack of measurements and analyses on the protein level and the need for a suitable animal model to test the therapeutic effect of the drug candidate on the physiological level. To overcome these limitations should be considered as the major objectives of further studies.

\section{CONCLUSION}

Together with the present study, we found that benzimidazole derivative ORT-83 exerted an antiinflammatory effect on A549 cells by suppressing the gene expression of pro-inflammatory cytokines. Besides, ORT-83 is a potent anti-inflammatory compound despite the fact that it has a milder inhibitory effect on COX-2 compared to the COX-2 inhibitor Dex.

Funding: This project was supported by Hatay Mustafa Kemal University Scientific Research Projects Funding with project number 15704.

Conflicts of Interest: The authors declare no conflict of interest.

\section{REFERENCES}

1. Libby P. Inflammatory mechanisms: the molecular basis of inflammation and disease. Nutrition reviews. 2007 Dec;65(12 Pt 2):S140-6.

2. Liu M, Fang G, Yin S, Zhao X, Zhang C, Li J, et al. Caffeic Acid Prevented LPS-Induced Injury of Primary Bovine Mammary Epithelial Cells through Inhibiting NF-kB and MAPK Activation. Mediators of Inflammation. 2019 Apr;1897820:1-12.

3. Liu T, Zhang L, Joo D, Sun SC. NF-kappaB signaling in inflammation. Signal transduction and targeted therapy. $2017 ; 2$.

4. Ayyad RR, Sakr HM, El-Gamal KM, Eissa IH, HA A, Tita AS, et al. Anti-Inflammatory, Proton Pump Inhibitor and Synthesis of Some New Benzimidazole Derivatives. Der Chemica Sinica. 2017;8(1):184-97. 
5. Simmons DL. What makes a good anti-inflammatory drug target? Drug discovery today. 2006 Mar;11(5-6):210-9.

6. Dursunoglu D, Dursunoglu N. Uyku apnesinin klinik uygulamasında kardiyovasküler biyobelirteçler. Tüberküloz ve Toraks Dergisi. 2011;59(4):402-8.

7. Hwang D, Kang M-j, Jo MJ, Seo YB, Park NG, Kim G-D. Anti-Inflammatory Activity of $\beta$-thymosin Peptide Derived from Pacific Oyster (Crassostrea gigas) on NO and PGE2 Production by Down-Regulating NF-kB in LPS-Induced RAW264. 7 Macrophage Cells. Marine drugs. 2019;17(2):129.

8. Lee HJ, Hyun E-A, Yoon WJ, Kim BH, Rhee MH, Kang HK, et al. In vitro anti-inflammatory and anti-oxidative effects of Cinnamomum camphora extracts. Journal of ethnopharmacology. 2006;103(2):208-16.

9. Rathore A, A Siddiqui A, Ali A, Shahar Yar M. Synthesis and evaluation of benzimidazole derivatives as selective COX-2 inhibitors. Medicinal Chemistry. 2015;11(2):188-99.

10.Gaba M, Singh S, Mohan C. Benzimidazole: an emerging scaffold for analgesic and anti-inflammatory agents. European journal of medicinal chemistry. 2014;76:494-505.

11. Gaba M, Gaba P, Uppal D, Dhingra N, Bahia MS, Silakari O, et al. Benzimidazole derivatives: search for GI-friendly anti-inflammatory analgesic agents. Acta Pharmaceutica Sinica B. 2015;5(4):337-42.

12.Ayhan-Kılcıgil G, Kus C, Özdamar ED, Can-Eke B, Iscan M. Synthesis and antioxidant capacities of some new benzimidazole derivatives. Archiv der Pharmazie: An International Journal Pharmaceutical and Medicinal Chemistry. 2007;340(11):607-11.

13. Bansal Y, Silakari O. The therapeutic journey of benzimidazoles: a review. Bioorganic \& medicinal chemistry. 2012 Nov 1;20(21):6208-36.

14. Nile SH, Kumar B, Park SW. In vitro evaluation of selected benzimidazole derivatives as an antioxidant and xanthine oxidase inhibitors. Chemical biology \& drug design. 2013 Sep;82(3):290-5.

15.Zhou B, Li B, Yi W, Bu X, Ma L. Synthesis, antioxidant, and antimicrobial evaluation of some 2-arylbenzimidazole derivatives. Bioorganic \& medicinal chemistry letters. 2013;23(13):3759-63.

16. Sharma M, Kohli D, Sharma S, Sharma A. Synthesis and antihypertensive activity of some new benzimidazole derivatives of 4'-(6-methoxy-2-substituted-benzimidazole-1-ylmethyl)-biphenyl-2-carboxylic acid in the presences of BF3. OEt2. Pharmacia Sinica. 2010;1:104-15.

17. Yadav S, Narasimhan B. Perspectives of benzimidazole derivatives as anticancer agents in the new era. Anti-Cancer Agents in Medicinal Chemistry (Formerly Current Medicinal Chemistry-Anti-Cancer Agents). 2016;16(11):1403-25.

18.Abad M, Bessa A, Ballarin B, Aragón O, Gonzales E, Bermejo P. Anti-inflammatory activity of four Bolivian Baccharis species (Compositae). Journal of ethnopharmacology. 2006;103(3):338-44.

19.Kim YS, Park JS, Jee YK, Lee KY. Dexamethasone Inhibits TRAIL-and Anti-cancer Drugs-induced Cell Death in A549 Cells through Inducing NF-kB-independent clAP2 Expression. Cancer research and treatment: official journal of Korean Cancer Association. 2004;36(5):330.

20.Patil RH, Naveen Kumar M, Kiran Kumar KM, Nagesh R, Kavya K, Babu RL, et al. Dexamethasone inhibits inflammatory response via down regulation of AP-1 transcription factor in human lung epithelial cells. Gene. 2018 Mar 1;645:85-94.

21.Boggu P, Venkateswararao E, Manickam M, Kwak D, Kim Y, Jung S-H. Exploration of 2-benzylbenzimidazole scaffold as novel inhibitor of NF-kB. Bioorganic \& medicinal chemistry. 2016;24(8):1872-8.

22. Tuglu C, Kara S. Depresyon, sitokinler ve bağışıklık sistemi. Klinik Psikofarmakoloji Bülteni. 2003;13:142-50.

23. Yang H-M, Zhuo J-Y, Sun C-Y, Nie J, Yuan J, Liu Y-L, et al. Pogostone attenuates TNF- $\alpha$-induced injury in A549 cells via inhibiting NF-KB and activating Nrf2 pathways. International immunopharmacology. 2018;62:15-22.

24. Liou C-J, Huang W-C. Casticin inhibits interleukin-1 $\beta$-induced ICAM-1 and MUC5AC expression by blocking NF-kB, PI3K-Akt, and MAPK signaling in human lung epithelial cells. Oncotarget. 2017;8(60):101175.

25. Hazekawa M, Ono K, Nishinakagawa T, Kawakubo-Yasukochi T, Nakashima M. In Vitro Anti-inflammatory Effects of the Phenylbutyric Acid Metabolite Phenylacetyl Glutamine. Biological \& pharmaceutical bulletin. 2018 Jun $1 ; 41(6): 961-6$.

26. Huang W-C, Wu S-J, Tu R-S, Lai Y-R, Liou C-J. Phloretin inhibits interleukin-1 $\beta$-induced COX-2 and ICAM-1 expression through inhibition of MAPK, Akt, and NF-kB signaling in human lung epithelial cells. Food \& function. 2015;6(6):1960-7.

27.Kuzu M. İnflamasyon, sistemik inflamatuvar reaksiyon sendromu ve peritonitin fizyopatolojisi. Hastane İnfeksiyonları Dergisi. 2001;5:69-83.

28. Ravichandran K, Tyagi A, Deep G, Agarwal C, Agarwal R. Interleukin-1beta-induced iNOS expression in human lung carcinoma A549 cells: involvement of STAT and MAPK pathways. Indian journal of experimental biology. 2011 Nov;49(11):840-7.

(C) 2020 by the authors. Submitted for possible open access publication under the terms and conditions of the Creative Commons Attribution (CC BY NC) license (https://creativecommons.org/licenses/by-nc/4.0/). 